\title{
FRANCIS AKANU IBIAM (1906-1995): A LEADER WHO HAD A MISSION BEYOND ECCLESIA
}

\section{Julius Gathogo 1}

Research Institute for Theology and Religion

University of South Africa

jgathogom@yahoo.com / jumgathogo@gmail.com

\section{ABSTRACT}

Sir Francis Akanu Ibiam KCMG, KBE (1906-1995) was a distinguished medical missionary who was appointed Governor of Eastern Region, Nigeria from December 1960 until January 1966 during the Nigerian First Republic. From 1919 to 1951 he was known as Francis Ibiam, and from 1951 to 1967 as Sir Francis Ibiam. This article explores his profile; the profile of a man whose contribution as a medical doctor, a missionary doctor, an educationist, a statesman and a churchman is outstanding, hence inspiring to the new crop of leadership in Africa of the $21^{\text {st }}$ century. Was he too emotional when conducting his political discourses? Did he make the right choices all along? Does his role in the Biafra War of 1967 with the government of Nigeria smack of his main weakness as a public servant? Nevertheless, he comes out in this article as one of the early pre-colonial professionals in Africa who had received a quality education during the dark days of African history, who had worked hard to remain relevant in their days; and who are indeed relevant in the $21^{\text {st }}$ century. In Francis Ibiam, the article shows a decisive leader who chose to work for the church rather than the colonial government, thereby making a strong statement that the church can be developed into an alternative forum of progress, a kind of alternative government where the deprived can still find justice, a job and other lifetime comforts. Despite the article being greatly indebted to Agwu Kalu's book, Dr Ibiam: The challenge of his life (1986), it has also derived materials from the internet and other published works. Certainly, it is geared towards celebrating a leader who had a mission beyond ecclesia.

Key words: Sir Francis Akanu Ibiam; Eastern Region, Nigeria; missionary doctor; Biafra War.

\section{UNISA $\cong$}




\section{Introduction}

Francis Akanu Ibiam, also known as 'Sir Francis Ibiam', was born on 29 November 1906 at Unwara on the banks of the Upper River about fifteen kilometres south east of Afikpo, in the Imo state of Nigeria. ${ }^{2}$ He was the second born son of Chief Ibiam Aka. Aka was a well-respected traditional leader of the Unwara clan. ${ }^{3} \mathrm{He}$ died when his son, Ibiam, was barely a year old. Nevertheless, Ibiam was named, as his Igbo culture dictated, after one of his prominent maternal uncles. ${ }^{4}$

Under the auspices of the Church of Scotland Mission, Christianity had spread into Unwara from Calabar through the Cross River in 1988. Consequently Unwara became the first foothold of the mission into Igboland. As a result, the Scottish mission had established a primary school in Unwara town by the beginning of the twentieth century. This opening of a primary school in the locality was, however, met with resistance by the locals who preferred to keep their children on the farms. As fate would have it, Ibiam was one of the lucky few who were sent to Unwara Primary School - since one of his relatives was teaching at the same school. ${ }^{5}$

Fortunately Ibiam had a very responsible elder brother, Samuel Aka Ibiam, in those dark days of British colonial hegemony. Samuel had by then managed to rise through the ranks to a position of being a tutor at the Hope Waddell Training Institution in Calabar. Subsequently, he shortened Francis Ibiam's stay at Unwara Primary School when he got him admitted into the primary school section of Hope Waddell in 1912. ${ }^{6}$ Why? Samuel considered Hope Waddell a more advanced academic institution than the 'newly' started Unwara Primary School. As such, he desired his brother, Ibiam, to get the highest quality of education possible.

\section{From agriculture to medicine: Shift in interest?}

Ibiam's interest in agriculture got a setback when a Dr Adams came to Hope Waddell to give a motivational speech to the attentive students. In the ensuing captivating speech, entitled: 'How to give first-aid to accident victims,' Ibiam found himself confessing: 'Oh! I must become a doctor.'" This lecture thus brought about a paradigm shift from interest in agriculture to medicine. As expected, his supportive brother, Samuel, was willing to sponsor him to study such a professional course. Unfortunately, Hope Waddell did not offer subjects like Latin, physics, chemistry and biology, which are basic to any medical career. In turn, this made him realise that for him to pursue a medical career, he had to attend King's College in the city of Lagos. Luckily, he was able to leave Hope Waddell for King's College in February 1921.

In 1924, Ibiam completed his education at King's College after passing his Senior Certificate with distinction. ${ }^{8}$ On 22 May 1925, he sailed for England in the company of Mr H.A. Harman, his former principal at King's College. Upon their arrival in Liverpool, in two weeks' time, Ibiam sat for his entrance examination at Glasgow 
University, and by October 1925 he had gained admission to study medicine. While in the UK, he realised that Glasgow city was of particular interest to him. Why? It was the largest city he had ever seen; it opened up further curiosity in him; and it is in this city that he found himself in the largest class ever. Interestingly, he only spent a semester at Glasgow University before he moved to London where he studied chemistry, physics, zoology and botany at a polytechnic.

By the end of 1926, Ibiam had entered Cambridge University but found it to be too expensive. He discontinued his medical studies in preference for agriculture. When his compassionate brother, Samuel, heard that Ibiam had dropped out of the medical course, he cabled him to express his disapproval of the new development. Samuel expressed his concerns that the arguments his brother had employed as reasons for dropping out of his medical studies, were not convincing. In particular, his contention that it was cheaper to study agriculture than medicine, should not have been a concern as it was Samuel who was footing the bill. Samuel thought Ibiam was perhaps becoming too concerned that Samuel could be under financial strain. Had he turned out to be a very responsible person at that very early age?

Samuel's rejection of Ibiam's proposal to shift from medicine to agriculture convinced Ibiam that he had no other choice but to obey his guru-brother. Thus by the age of 21 he had again started to settle down to his medical studies, albeit undecidedly. During this path on the way forward with regard to his academic pursuance, an old friend from Hope Waddell Institution (Ekpenyong Itam) suggested that his problems could be solved if he transferred to St. Andrew's University in Scotland. This was his 'new' way of addressing his concerns about the high cost of a medical education.

Eventually, in October 1927, Ibiam got admission to St. Andrew's University in Scotland. As a result of problems caused by the re-adjustments, he was to complete his studies two years behind schedule. This robbed him of a chance to become the first Nigerian to return as a qualified Igbo medical doctor, ahead of Kodilinye and Simon Onwu, both of whom were his contemporaries at other British universities. During his stay in Scotland, Ibiam proved that he was both a good strategist and an Africanist. This is seen in the fact that he organised the first Igbo Students' Union in Great Britain. To start with, the association was a triad that comprised of Kodilinye, Onwu and Ibiam. Accordingly, the venue for their meetings rotated between London, Glasgow and St. Andrew's, where each was a student. One interesting aspect of this association is that they had a constitution that insisted on a 'fine' in case of default by speaking in the English language rather than in their Nigerian language, Igbo.

\section{Ibiam's return after overseas studies}

Ibiam returned to Nigeria in August 1935 and he immediately took over as a medical worker in the missionary centres. This came after he had applied to the 
Church of Scotland Mission for employment as a mission doctor, a development that took the clerk of the Synod of the Church of Scotland by surprise. Why? Ibiam, being a qualified medical doctor, could easily have acquired a job with the colonial authorities. However, having seen how the white legal officers discriminated against and withheld the progress of their educated African counterparts, he felt it wiser to work with the church, which was more accommodating than the colonial government.

Indeed, Ibiam had been offered a job by the Nigerian Government at Sokoto, but as a responsible person he realised that his profession would not bear much fruit in an environment where there was overwhelming suppression. Again, he also wanted to work in a place that was closer to his sick mother whom he would have wanted to care for. ${ }^{9}$ It is against this background that Ibiam decided to take up the role of a missionary doctor. Eventually, he was invited by the church mission to open a new hospital either at Ohafia or Abiriba. He chose the latter as it was a trading area where the locals were expected to sustain it financially. Thus on 1 February 1936 a dispensary was set up, and as time went by, it was expanded into a full hospital. In turn, the hospital served a wide area comprising Abiriba, Ohafia, Item, Igbere and other environs.

As a community leader, Ibiam rallied the community to form the Abiriba Improvement Union. With his emerging influence the community was able to send their first son, Elder Barrister Chief E.O. Emde, to study law in Britain. Furthermore, apart from building his own hospital, he also recruited and trained his own staff, and even though he pushed the Mission Council to ask for nursing sisters, it was only in 1943 that a nurse came to Itu. Nevertheless, a nurse training programme commenced in 1950, thereby fulfilling his long-held dream.

Ibiam only experienced problems with the white missionaries later when he discovered that they exhibited racial superiority over his person as a black missionary. This is evidenced by the fact that most of his European counterparts were provided with cars, while he was reduced to a mere bicycle rider. In addition, Ibiam, unlike his European colleagues in the mission stations, did not receive children allowances. In other words, a black doctor did not have anyone to look after his or her family or social welfare. Ibiam was disturbed by this scenario where some were more equal than others - yet in Galatians 3:28, St. Paul says clearly that in Christ there is no Jew nor Greek, no woman nor man - as Christ has made us all equal. One could ask: Are there missionaries who are less human than others? Doesn't the great commission (Matthew 28:18-20) direct us to attend to God's people equally, regardless of creed, gender, colour, status, pedigree or other backgrounds? Ibiam feared that such discrimination on racial grounds could have been a clever way of forcing him to resign, thereby making a mockery of black ministry by rendering it unworkable. Confronted by the idea of either resigning or suffering great stress, Ibiam chose to petition the Mission Council. He wrote a letter that drew the council's attention to the numerous 'acts of discrimination against his person', while at the same time 'making it clear that nobody could discourage him from further missionary work' ${ }^{10}$ 
Ibiam's petition to the Mission Council was largely ignored, as it took long before any response came forth. In 1945, however, the council sent a delegation of four to discuss the content of his letter with him. Rev. R.M. Macdonald led the delegation and they met him at Abiriba. To add insult to injury, the council did not appear to have adequately attended to the issues that Ibiam had addressed. No sooner had the delegation left the gates of the hospital, than a letter came from Itu. This letter transferred Ibiam to Itu Hospital, thereby shelving the problems at Abiriba Mission Station. Ibiam was to work at Itu until 1951.

\section{Marriage to Eudora}

After 15 years of courtship, Ibiam married Miss Eudora Olayinka Shashebon, who hailed from a very prominent family in Lagos, Nigeria. She was already a higher elementary school teacher who had also studied in England and had also qualified as a midwife. Being a midwife, Eudora became a big asset to Ibiam in the medical profession. Together they gallantly fought against some Igbo traditions which were incompatible with the gospel of Christ. Some of these traditions included the killing of twins, as it was considered a bad omen. At one time, Mr and Mrs Ibiam had almost ten twins to feed in their house, after their parents had insisted on killing them.

Additionally, $\mathrm{Mr}$ and Mrs Ibiam undertook the responsibility of educating the populace on the need to discard the 'old superstitious aversions to Western medicine'. ${ }^{11}$ It is necessary to appreciate that the wedding of Ibiam and his supportive wife, Eudora, was solemnised 'at the famous Christ Church Cathedral along the Marina in Lagos ${ }^{12}$ Nigeria.

\section{Ibiam's view on witchcraft and superstition}

As an African and a member of the Igbo culture, Ibiam understood the impact of superstition and witchcraft on his people. These beliefs caused the people to attribute all their problems (be it barrenness, the birth of twins, malaria, miscarriages, fever, or a stroke) to demonic attacks. Interestingly, Ibiam was bold and fearless but sympathetic in dispelling these fears from the minds of his patients. He gave them physical healing through Western medicine, and spiritual and emotional healing through the dynamic preaching of the gospel of Christ. He made it his habit to always remind his audience to free themselves from the miseries and fears of witchcraft and superstitious beliefs. Instead, he encouraged his audiences, whether on the pulpit or while inside his consultation room, to always accept the efficacy of modern medicine.

Like the pioneers of African nationalism, Ibiam made it his agenda to combat ignorance, disease and poverty. In his view, superstitious beliefs clearly demonstrated ignorance. During his practising career, the belief in witchcraft as a type of sorcery was evident as an established institution among the peoples of Uburu/Oha-Ozara, 
Abiriba and Itu. This made his missionary career also a mission of addressing the above vice.

In particular, barrenness in a woman was always seen as a result of witchcraft. Similarly, the death of a child or a relative was believed to be caused by wizardry; a sudden heart attack was seen to be caused by some human meat. Furthermore, witches and wizards were characterised by cannibalistic orgies, which were celebrated with wild dancing, drinking and singing. In addition, witch-hunts were common and the so-called witchdoctors commanded a lot of influence in the rural societies. ${ }^{13}$

Superstitious beliefs about witchcraft were a great social drawback to the society in general, as they spread fear, panic, and even death. From the above, we realise that the missionary tasks of Ibiam included a relentless crusade against fears of witchcraft. This was not a simple matter for him. Consequently, he discovered that it was too deep-rooted in the society, and that it would take a long time to eradicate it. Why? Being connected to the African indigenous religiosity made it part of the day-to-day way of living. Ibiam therefore became convinced that 'only an informed religion, proper education, scientific medicine and better social conditions could eventually dispel its myths and free mankind (sic) from one of the greatest fears and haunts of all time'. ${ }^{14}$

\section{The challenge of female circumcision}

Another challenge in Ibiam's career as a mission doctor is female circumcision. In his practising career, female genital mutilation was being practised in many places. Unfortunately, it characteristically brought about unnecessary bleeding, infections and even death to women. During the 1943 National Synod of his Presbyterian Church, Ibiam came out strongly against it, thereby influencing the agenda of the moment. In a well prepared paper, he strongly gave reasons why it should be abandoned. He also used the opportunity to show the role of the church in eradicating it. Fortunately, his Presbyterian Church Synod gave him support. Subsequently, the Synod asked him to translate his notes from English into the Igbo and Efik languages - both of which he was fluent in. These translations were to be included later in the appendix of the Synod books in the 1944 minutes.

\section{Ibiam and homiletics}

With regard to preaching, Ibiam saw it as the panacea for the society regarding various challenges. As the engine of the church's mission, Ibiam argued that preaching should never be misused. The cross of Christ, he argued, is central in any Christian preaching. To be an effective and genuine preacher, one must not confine oneself to the pulpit. Rather, Christian preaching and testimony must be accomplished even in the streets, the market places, the cities, the work place, and the offices, among other places. This compares with Jesus' market theology approach to the ministry, where 
he went to the market places, the fields and other places where people gathered; as opposed to waiting for the people in the temple or in the synagogues.

\section{Ibiam as a rural-based operator}

To demonstrate his creed, Ibiam chose to work in rural areas as opposed to urban areas. He saw it as the sure way of empowering the uninformed population within rural areas. He could also have wanted to make a strong statement to the upcoming elite that the place to serve is in the rural areas - where there is a lot to do. One may regret that several decades since Ibiam showed the way, most African professionals still rebel at the idea of working in rural areas. If this trend continues, who will give the service to the masses? How will these rural areas develop without the dedication and return of their sons and daughters who are professionals in various fields?

In the case of addressing social challenges such as superstition and witchcraft, female genital mutilation, education for the girl-child and empowering the masses, among others, Ibiam argued that only the professionals could competently change the tide. This portrays Ibiam as a responsible leader who chose to work in the place where his services were needed most. This article contends that it is the real challenge for African elites today.

\section{Ibiam as a Pan-Africanist}

In his booklet, What about Africa? Ibiam expresses his dream of Pan-African evangelism. In this booklet Ibiam states what he considers to be the ideal life of a missionary. He also explains the factors that formed the missionary in him. He explains his case against European missionaries and goes on to suggest what ought to be done to realise his dream of a Christianised and self-supporting African continent. ${ }^{15} \mathrm{In}$ his dream for a Pan-African evangelism, Ibiam sees Africa as a continent which can employ more or less the same methodology in its evangelisation. He describes his notion of 'missionaries' as those 'who have borne and are bearing the brunt of what is a life unavoidably and peculiarly tinged with hardships, difficulties and trials, but which is at the same time richly rewarding and satisfying in the spiritual things of life, if not in worldly goods and possessions'. ${ }^{16}$ While admitting his appreciation for mission work, Ibiam noted that the missionaries derive their satisfaction not from material acquisitions. They find satisfaction despite hardships that they encounter because they have dedicated themselves to a special job under special conditions (which are mainly restrictive and uphill) and because they derive their fulfilment from Jesus Christ, their Lord and Saviour.

In short, Ibiam's view of mission work is that a missionary should simply be guided by the great commandment of love (Mark 12:28-31) and the great commission (Matthew 28:18-20). This means that as a life of dedication and commitment, a missionary's primary and sole objective is to do the will of God. Missionary work is 
not meant to be self-enriching or looking for status in the society. A dedicated servant will not be discouraged by the hardships that he or she encounters. This makes missionary work interesting. It is with that in mind that missionaries accept their life style, all in the name of their Lord and Saviour, Jesus Christ and also for His sake. For a Pan-African evangelism dream to take place, such dedication is necessary.

Upon his arrival to the European city of Aberdeen, Ibiam was moved by its beauty, its cleanliness and its modern outlook. He was bewildered because some European missionaries, whom he personally knew, had agreed to leave their home place of affluence to come to his own non-industrialised hometown of Unwara. This made him see the convincing power of Jesus Christ. He nevertheless noted a few challenges with some European missionaries in his homeland: 'It is true to say that missionaries inspired me, but, strange to say, they did not encourage me. ${ }^{17}$

Why did Ibiam feel 'discouraged' by the European missionaries in his homeland? This may point to the discriminatory attitudes that he claims to have encountered in the mission centres. As noted earlier, the discriminations reached their zenith when he 'petitioned' in 1944, while at Abiriba. With such discrimination in mind, Ibiam stated that "the very white man who planted Christianity on the soil of Africa is by what he says, by what he does, and by his way of living, loudly and vigorously uprooting that which he has heroically planted'. ${ }^{18}$

Ibiam observed that white missionaries would begin their church ministries well but would later turn out to be apologists of white supremacy. He observed in disbelief that older missionaries in the field were tutoring their new colleagues on the "way to deal with the Africans'. In particular, the older missionaries would discourage the incoming ones not to be friendly and integrated with the Africans. Interestingly, those who would break that 'rule' of separation (or is it separate development?) would meet stiff resistance from others. In some cases, such 'defiant' missionaries would not return after a first or second tour of duty.

Ibiam did not like the way some European missionaries lived within a special clique and in a world of their own. Some were fond of giving orders, irrespective of their newness to the environment. Consequently, the African was made to feel that he/she knew nothing, despite his or her vast experience in the particular job that he or she was undertaking.

Ibiam also saw the white missionaries as contradicting St. Paul's approach in mission, as seen in the New Testament. In particular, they were not keen to visit the homes of African Christians, much less the homes of non-Christians. In the case of St. Paul, his colleagues were never arrogant about their Roman citizenship and disparaging towards their fellow Christians and those whom they sought to convert. As a result, Ibiam proposed the need to remove all stumbling blocks such as 'discriminatory practices'. He wrote:

Pious, apologetic statements from government officials will not heal the wounds. It is either complete acceptance of one people by another as equals, or "friendly" relations may as well be broken off to stop this insult and hypocrisy. ${ }^{19}$ 
As a person who had a Pan-African dream of equality for all who live in Africa, Ibiam at one stage in 1960 flared up when many Europeans in the present day Zimbabwe (formerly Rhodesia) vociferously protested against the public swimming pools being opened to all races. About that multi-racial controversy, Ibiam said:

Doctors have been quoted in the press as saying that chlorine in the water was a sufficient safeguard against disease, but one expert described as a leading Salisbury [now Harare City of Zimbabwe] doctor said that he was alarmed at the possibility of disease transmitted from Africans to Europeans at the swimming baths. ${ }^{20}$

In the above description Ibiam was trying to express the derogatory remarks that tended to downplay the dignity of the African; that is, the assumption that only Africans carry and transmit diseases. Such an argument was certain to widen the gap in race relations during his times.

With regard to the crisis in Congo (currently the Democratic Republic of Congo or DRC) of the 1960s, Ibiam expressed his view that the confusion which was rampant could have been solved. He cited the case of the unification of Germany under the leadership of the charismatic Otto Von Bismarck (1815-1898) in 1871 as a success story worth being emulated, and worth serving as lessons to the then Congo. He blamed the Western powers for their lack of commitment to the Congo crisis, which saw the death of the charismatic leader, Patrice Lumumba (1925-1961) and the military take-over under General Mobutu Seseko (1930-1997) as president in 1961. Ibiam felt that if the crisis had been well addressed it could have saved the life of Dag Hammarskjoeld (1905-1961), one of the finest Christian men of the twentieth century. His death occurred en route to cease-fire negotiations in the present day Democratic Republic of Congo. ${ }^{21}$ Until he died in 1961, Hammarskjoeld, who was described by US President John F. Kennedy (1917-1963) as 'the greatest statesman of our century', was the Secretary-General of the United Nations. ${ }^{22}$ Dag Hjalmar Agne Carl Hammarskjöld was a Swedish diplomat, economist, author and the second Secretary-General of the United Nations who served from April 1953 until his death in a plane crash on 18 September 1961, at the age of 47 . He is one of only three people to be awarded a posthumous Nobel Prize.

\section{Ibiam as the Governor for Eastern Nigeria}

Following his successful tenure as a medical practitioner, hospital administrator, and as principal of Hope Waddell, Ibiam was greatly sought after even by the senior members of the local government of Eastern Nigeria. In September 1960 he and his wife, Lady Ibiam, were honourably invited to Lagos to join other eminent Nigerians at a state service to commemorate the country's attainment of independence after 60 years of British rule. At this service, which was held at the Church of Christ Cathedral on the Marina in Lagos, Sir Francis Ibiam met other prominent Nigerians such as Dr Nnamdi Azikiwe, the new Governor-General of the Federation; Chief 
Festus Okotie-Eboh, the Federal Minister of Finance; Honourable Dr Michael L. Okpara, Premier of the Eastern Region, and a host of other personalities. At the close of the service, Okpara rushed to Ibiam and made it clear to him that the new nation was in need of him to serve it. He revealed to him that 'we have been looking for you, do please come over to the State House, Marina for a chat'. ${ }^{23}$ It was during the State House meeting that Okpara told him that his government had been screening possible candidates for the vacant post of Governor for Eastern Nigeria.

Subsequently, the cabinet unanimously endorsed Ibiam's candidature, and even though Ibiam had previously vowed never to work for the government, he eventually changed his mind and accepted to serve in the new capacity. His acceptance was followed by the radio Nigeria announcement that Ibiam had been named the new Governor for the Eastern Region. This resulted in jubilations, especially at Afikpo town. In turn, the Mission Council granted him a 'leave of absence' to enable him to move into the State House, Enugu.

On 21 October 1960 Ibiam was sworn in as the new Governor of the Eastern Region of Nigeria at a colourful ceremony at the Enugu Sports Stadium. In the following years he was to lead with his deeply seated Christian virtues. In particular, he influenced Okpara's cabinet with the Christian virtues of justice, honesty, discipline, fear of God, humility and respect for everyone. He would start every cabinet meeting with a short sermon, and this influenced the governance of the entire region.

One climactic moment was when Ibiam convinced Premier Okpara that his entire cabinet should not operate personal bank accounts abroad. Why? He was fighting corruption from the top level of governance and this ensured that the cabinet ministers did not acquire any ill-gotten wealth. This proposal by Ibiam proved so successful that even Premier Okpara did not rush to erect his private residence until the 1980s; and this was not even completed at the time of his death in 1985. In short, the public officers did not steal from the public coffers, as Ibiam spoke strongly against such vices.

As Governor, Ibiam discovered that he stood a better chance of being heard by a wider audience. In view of this he used the opportunity to address the ills that plagued the nation. Consequently he denounced vices such as tribalism, nepotism and corruption. He also noted that even though he was used to a 'low profile' lifestyle, he could do little to brush aside the usual government protocol and bureaucracy that surround a government office. In particular, a person in the stature of a governor was driven to ceremonial occasions in a Rolls-Royce and was being addressed as 'His Excellency'. Additionally, it also became difficult for him to find time to preach in church services of his choice. 


\section{Ibiam and negative ethnicity}

With reference to Nigeria, Ibiam was convinced that negative ethnicity (wrongly referred to as tribalism) was responsible for the rejection of the 1963 national census figures. For indeed, each of the major ethnic groups in Nigeria (Igbo and Yoruba ethnic groups) wanted to ensure that it could always grab the greatest number of seats at the national assembly. A big ethnic group, in terms of numbers, would also receive the greatest portion of the national cake, especially with regard to the statutory revenue allocation. In his view, this quest (by the federal government) to control 'power' for one's particular ethnic group also contributed to the deadlock in the 1965 federal government elections. In Ibiam's view, the increase of crime and the general cases of arson were also a result of negative ethnicity. In particular he felt that the Hausa controlled the central, northern and western regions, while the Igbos clung to their eastern and mid-western regions, thereby leaving the other Nigerian tribes fearful and disgruntled. Additionally, he consistently condemned national appointments that were based on tribal affiliation and not on merit. $\mathrm{He}$ publicly lamented the enthronement of 'mediocrity' in the place of 'meritocracy' in the nation's civil service and government appointments; which he deemed as byproducts of tribalism.

\section{Nigeria's military coup and Ibiam's retirement as a governor}

During the January 1966 military coup, otherwise called the Nzeogwu coup, MajorGeneral Aguiyi-Ironsi was brought to power as Nigeria's new head of state. Similarly, Lieutenant Colonel Odumegwu Ojukwu became the military governor of the Eastern Region, and Governor Ibiam was immediately retired. Afterwards the Nigerian Civil War, otherwise called the Biafran War of 1967, followed. During the Biafran War, where Biafra Province wanted to secede from the country of Nigeria, Ibiam played the role of a political adviser to the new military governor, Ojukwu. Ibiam personally believed in the Biafran cause, as he saw the Eastern Region as genuinely fighting for its survival since the rest of Nigeria did not want them any longer. But was Ibiam's support for the Biafran War tantamount to embracing tribalism through the backdoor?

The most interesting dimension of Ibiam's role during the Civil War is that he moved from village to village, and from town to town, to solicit enlistment into the Biafran army. Like Jürgen Moltmann (1926 - ) during the Second World War (19391945), Ibiam went personally to the war fronts and military camps to say words of encouragement to the Biafran soldiers. In particular, he would encourage his people that God will sustain them to the end. When his Unwara people became 'refugees' at Nguzu Edda in 1968, Ibiam went there to encourage them that their destroyed town of Unwara would one day spring up again. ${ }^{24}$ 
As the war progressed, Sir Francis Ibiam denounced his accolade in August 1967. He wrote a letter to the Queen of Britain that he had come to regard it illogical to wear the insignia of his knighthood from the same Britain who earlier held him in high esteem, but was then backing the federal troops with dangerous weapons to eliminate his person and his people. He could not understand why Britain was behind the economic blockade on Biafra - a phenomenon that led to the starvation of the Biafran populace. He therefore made it clear that it was his wish to cease being known as 'Sir Francis' but simply 'Dr Akanu Ibiam'. To do this, he requested that his declaration be conveyed to the Queen through the British High Commissioner in Enugu. In the letter to Her Majesty Queen Elizabeth II, Ibiam said:

Your Gracious Majesty,

I am deeply and humbly constrained to present you with this letter.

During the months of May, July, August, and September, 1966, Northern Nigerian soldiers and civilians planned and committed the most atrocious crimes against Eastern Nigerians - now citizens of the Republic of Biafra. Sadistically, brutally and in cold blood, they murdered and slaughtered thousands of my brothers and sisters who were then living in Northern Nigeria and other parts of the former and defunct Federal Republic of Nigeria. They killed innocent children, helpless women, and defenseless men without any reason or rhyme. They entered churches and hospitals and slaughtered them in cold blood. And most unbelievably yet only too true, they massacred women in actual LABOUR and their unborn children. They plundered, looted, assaulted and raped women and burnt down the homes of Easterners and left them penniless...

In the succeeding months, the Hausa/Fulani controlled Lagos Government of Nigeria purposely, directly, and inexorably forced Eastern Nigeria out of the Federation, and our Military Governor with advice and consent of our Consultative Assembly had no other choice but to declare Eastern Nigeria a free, independent and sovereign state to be known as the Republic of Biafra. This happy and historical occasion took place on May 30. On July 6th, Nigeria attacked Biafra in her mad wish to force Biafra to return to the Nigerian federation. Having killed 30,000 of us in their land and seized our property worth millions of pound sterling, they have now come to kill more of us in our own homes and make the rest of us slaves to the Hausa/Fulani Feudalists and Moslems.

The people of Biafra are, therefore, fighting a war of LIBERATION AND SURVIVAL. We adamantly refuse to be colonised by the Hausa/Fulanis of Northern Nigeria or any other people in the world. Moreover it is an ardent desire of the Hausa/Fulani and Moslem Northern Nigeria to subjugate Biafra and kill Christianity in our country...

It is simply staggering for a Christian country like Britain to help a Moslem country militarily to crush another Christian country like Biafra. This is just too much for me, Your Gracious Majesty, this act of unfriendliness and treachery by the British Government towards the people of Republic of Biafra who, as Eastern Nigerians, had so much regard for Britain and British people. 
In the circumstance, Your Majesty, I no longer wish to wear the garb of the British Knighthood. British fairplay, British justice, and the Englishman's word of honour which Biafra loved so much and cherished have become meaningless to Biafrans in general and to me in particular. Christian Britain has shamelessly let down Christian Biafra.

I love the Republic of Biafra very dearly and pray that, by grace of God, she may remain and continue to grow and live and always act like a truly Christian country for all times.

I am, Your Majesty

Yours Most Respectfully,

$(\text { AKANU IBIAM) })^{25}$

As a matter of fact, renunciation of his knighthood achieved for Biafra a diplomatic victory, for as an international figure, Ibiam's words were greeted at the Geneva headquarters of the World Council of Churches with the seriousness they deserved. In other words, he made the world to have some sympathy for the Biafran cause. As a result, the World Council of Churches acted quickly to arrest the ongoing starvation of the Biafran people. In particular, the World Council of Churches began to arrange relief supplies into Biafra. All this was a result of Ibiam's intervention, as noted above.

In 1969, the World Council of Churches asked Ibiam to visit them and thereby give the true picture of the Biafran war. Subsequently, Governor Ojukwu approved a three-week tour abroad for Ibiam, which was however extended. In November 1969 he flew out from Uli, the only remaining Airstrip in the Biafran enclave. ${ }^{26} \mathrm{In}$ the wake of all this, Ibiam, as a former president of the World Council of Churches, travelled to Geneva and other parts of the world to appeal for food and medical aid for the embattled and battered people of Biafra. During his tour abroad, thus, Ibiam urged the churches to dispatch more food, clothing, drugs and money. ${ }^{27}$

The Civil War finally ended in January 1970 when the federal troops closed in on Biafra on all fronts. As the war came to a close, Ibiam was still in Europe, specifically West Germany. When he heard that the war was over, he hurried back to Nigeria and had an audience with the head of the military government, General Yakubu Gowan, who assured him of his safety and gave him safe conduct to his home in Unwana in eastern Nigeria. After the cessation of hostilities Ibiam laboured with his fellow Biafrans to resettle themselves in their places of abode. He continued to be bold and fearless in his advocacy for justice and the equitable distribution of Nigerian resources. He served as a special advisor to the military governors in the eastern states of Nigeria. ${ }^{28}$

Upon his return from Europe and as the post-civil war reconciliation and reconstruction continued, Ibiam was appointed as special adviser to the governor of the East Central State by the Federal Military Government. Thus, since 1970, he served continuously under different governors. This included Godwin N. Kanu (1976-1979); Samuel Mbakwe (1979-1983); I.O.S Nwachukwu (19830-1985); 
Allison Maduekwe (1985-1986); Ahmadi Ikwechegh (September 1986); John A. Kpera (1976-1979); Emeka Omeruah (1985 -). As an adviser to the governors he was provided with official cars of two state governments (Ima and Anambra) simultaneously. ${ }^{29}$ Interestingly, Ibiam was called upon to advise successive heads of state, a fact which demonstrates how he was revered as a senior citizen of Nigeria, his country.

\section{Decoration with the title of Ezeogo Isiala}

Even though it is commonly said that a prophet is never accepted in his own homestead, Ibiam was decorated in 1993 with the traditional title of Ezeogo Isiala of Unwana, the local community where he was born. This traditional title was conferred upon him in recognition of his shining contributions to the welfare of his community and that of the nation at large. In continued recognition of his sterling contributions to the field of education, politics, medicine and Christian community service, Ibiam received many awards: the honorary doctorate degree of LLD was conferred upon him by the University of Ibadan; the DSc honorary degree by the University of Ife; he was elected chairman of the Christian Council of Nigeria $(\mathrm{CCN})$; and chairman of the Imo State Council of Chiefs. ${ }^{30}$

In summary, Ibiam was a key Christian figure, responsible for new initiatives such as the Bible Society of Nigeria and the Christian Medical Fellowship. He served as president of the Christian Council of Nigeria (1955-1958) and in many other capacities. He was also seen as an outstanding African ecumenical figure of the decolonisation period, serving as chairman of the conference that led to the birth of the All Africa Conference of Churches (AACC); a president of the All Africa Conference of Churches (AACC) and of the World Council of Churches; chairman of the Council of the United Bible Societies; and leader of the AACC peace mission to Sudan. In his home area he was a respected traditional ruler, Eze Ogo Isiala I of Unwana and Osuji of Uburu. Following his death in 1995 at the age of 89, he left a lasting legacy on all areas that he touched.

On the other hand, we have to ask the questions: Was Ibiam a victim of emotional decision-making blunders, especially with regard to his local national politics? By declaring Biafra (one of the states of Nigeria) as 'the Republic of Biafra', could this be seen as bordering on treason? While alleging that the people of Biafra state were 'fighting for survival and liberation' from the colonisation of the Muslim dominated Hausa/Fulanis of northern Nigeria, didn't it smack of religious intolerance, secessionist trends, ethnic disharmony and/or a negative myth that Africans cannot remain a cohesive society? These questions may be the topic of new research studies. This article concludes with the viewpoint that Ibiam made his contribution in the desperate moments of turbulent days in the African history. Certainly, desperate times call for desperate measures. 


\section{Conclusion}

The article began by retracing a profile of Francis Akanu Ibiam, a man whose contribution as a medical doctor, a missionary doctor, an educationist, a statesman and a churchman is outstanding and inspiring to the new crop of leadership in Africa of the $21^{\text {st }}$ century. In particular, the article explored his childhood, early school life, college life, university life, working life as a medical practitioner and as a political leader. His climactic role in handling the Biafra War with Nigeria in 1967, can also be seen as his main weakness, as he could be seen acting here mainly as a tribal leader. Nevertheless, his letter to the Queen of England, which played a critical role in ending the Civil War (among other critical contributions in both church and society) shows that Africa too has its own Winston Churchills ${ }^{31}$ - elders who would always step in during turbulent moments of our history. Certainly, his becoming the president of the All Africa Conference of Churches shows that he was able to balance his religious and political duties without losing his medical constituency; an achievement modern leaders can learn from him. In life or in death, his prominence was felt, for his funeral at Unwana in December 1995 was attended by over 20000 people. Moreover, the Akanu Ibiam International Airport, Enugu; the Akanu Ibiam Federal Polytechnic, Unwana, Ebonyi State; and the Francis Akanu Ibiam Stadium University of Nigeria, Nsukka, among others, are all named after him. The Africa of the $21^{\text {st }}$ century has learnt vital lessons from his life, his career and his profile.

\section{ENDNOTES}

1. Dr Julius Gathogo is a Research Fellow in the Research Institute for Theology and Religion, University of South Africa (UNISA)

2. See Ayandele 1970. Holy Johnson: Pioneer of African Nationalism, 1836-1917.

3. See Ayandele 1970.Holy Johnson...

4. Kalu 1986, Dr Ibiam... The challenge of his life,7.

5. Kalu 1986, Dr Ibiam... The challenge of his life, 7.

6. Kalu 1986, Dr Ibiam ...7

7. Kalu 1986. Dr Ibiam ...8.

8. See Kalu 1986.Dr Ibiam ... 10

9. Kalu 1986. Dr Ibiam ... 15

10. Kalu 1986. Dr Ibiam ... 17

11. Kalu 1986. Dr Ibiam ... 17.

12. Kalu 1986. Dr Ibiam ... 17.

13. See Kalu 1986.Dr Ibiam...21

14. Kalu 1986. Dr Ibiam ...22

15. Sir Francis A. Ibiam, What about Africa?

16. Sir Francis A. Ibiam, What about Africa? 21 
17. Sir Francis A. Ibiam, What about Africa? 22

18. Sir Francis A. Ibiam, What about Africa? 34

19. Sir Francis A. Ibiam, What about Africa? 35

20. Sir Francis A. Ibiam, What about Africa? 36

21. Linnér 2007. Dag Hammarskjöld and the Congo crisis, 1960-61, p. 28.

22. Important to note is that the Belgian Congo became the independent Republic of the Congo (now Democratic Republic of the Congo) on 30 June 1960, and Hammarskjöld sent a UN force to suppress the civil strife that began there soon afterward. In September 1960, his action was denounced by the Soviet Union, which demanded that he resign and that the office of secretary-general be replaced by a three-man board (troika) comprising representatives of the Western, communist, and neutral nations. Soon after, while on a peace mission to President Moise Tshombe (1919-1969) of the Congolese province of Katanga, Hammarskjöld was killed in an airplane crash.

23. Kalu 1986.Dr Ibiam...33.

24. See Uka, http://www.dacb.org/stories/nigeria/ibiam_akanu.html (accessed on 20 January 2015).

25. http://www.kwenu.com/biafra/Ibiam_Memo.htm (accessed on 20 January 2015).

26. Biafra's only link with the outside world was its airstrips - particularly the airstrip at Uli, code named 'Annabelle'. Relief flights reached Anabelle from Cotonou (Dahomey), Santa Isabelle (Fernando Po) and the Portuguese Island of Sao Tome. The nightly relief flights from Sao Tome started in April 1968, largely under the auspices of the Joint Church Aid (JCA) and also the International Committee of Red Cross (ICRC) which chartered aircraft, often at great cost, from whatever available source. The aircraft included DC-65, C-46 and a fleet of Super Constellation owned by the German -American entrepreneur Hank Warton. Later, four giant c-97 Strato-freighters were acquired from the US Government bringing the total number of available aircraft to 15 . The pilots had to evade radar controlled anti-aircraft batteries as they flew over Nigerian-held coastal districts of Biafra. Over Uli airstrip itself, they had to evade Ilyushin-28 bombers, which regularly patrolled the airspace for some four hours on most nights until 23:00. 'Intruders', as the twin jets were often called, did more harm by often holding up the landing of these vital relief flights than through their 500 pounders. (See D.C. Nwafor, http://www.kwenu. com/biafra/Ibiam_Memo.htm (accessed on 20 January 2015).

27. See Uka, http://www.dacb.org/stories/nigeria/ibiam_akanu.html

28. See Uka, http://www.dacb.org/stories/nigeria/ibiam_akanu.html (accessed on 20 January 2015).

29. See Kalu 1986.Dr Ibiam...45

30. See Uka, http://www.dacb.org/stories/nigeria/ibiam_akanu.html

31. Winston Churchill (1874-1965) was a British politician who was the Prime Minister of the United Kingdom from 1940 to 1945 and again from 1951 to 1955 . Widely regarded as one of the greatest wartime leaders of the twentieth century, Churchill was also an officer in the British army, a historian, a writer (as Winston S. Churchill), and an artist. 
He won the Nobel Prize in Literature, and was the first person to be made an honorary citizen of the United States.

\section{LIST OF REFERENCES}

Ayandele, E.A. 1970. Holy Johnson: Pioneer of African Nationalism, 1836-1917. London: Frank Class.

Gathogo, J. 2011. African hospitality from a missiological perspective. Saabrucken: LAP Lambert. Ibiam, Sir Francis A. 1961. What about Africa? Unwara.

Kalu, A. 1986. Dr Ibiam: The challenge of his life. Aba: The Presbyterian Church of Nigeria.

Linnér, S. 2007. Dag Hammarskjöld and the Congo crisis, 1960-61. Uppsala University Press.

Nwafor, D.C. (n.d.) http://www.kwenu.com/biafra/Ibiam_Memo.htm (accessed on 20 January 2015).

Uka, E.M. (n.d.) http://www.dacb.org/stories/nigeria/ibiam_akanu.html (accessed on 20 January 2015). 